\title{
China-Pakistan Economic Corridor: Ensuring Pakistan's Economic Benefits
}

\author{
Muhammad Ibrar ${ }^{*}$; Jianining $\mathrm{Mi}^{2}$; \\ Muhammad Rafiq ${ }^{3}$; Liaqat $\mathrm{Ali}^{4}$ \\ 1, 2,3 Harbin Institute of Technology, Harbin, P. R China; ${ }^{4}$ University of Sawabi, Sawabi, \\ Pakistan. \\ *Corresponding author: ibrarshabjani@yahoo.com
}

\begin{abstract}
The China-Pakistan Economic Corridor (CPEC) is a well-crafted economic partnership between China and Pakistan which is expected to bring economic development and prosperity not only for the two neighboring countries but also for the whole South Asia. It is considered central to China-Pakistan relations and the CPEC will link Kashgar to Gawadar port through the extension of Silk Road initiative which is widely known as Belt and Road Initiative (BRI). With the investment of 46 billion US dollars, its completion is expected by 2030. CPEC is the most discussed and debated economic partnership and it has great geostrategic importance for Pakistan to counterbalance Indian influence in South Asia. However, the focus on geopolitical and location of the route has been dominated the important questions concerning "How Pakistan should ensure its economic benefit out of this mega project?" This paper, therefore, aims to develop a theoretical framework and put forward relevant recommendations on how Pakistan can ensure its economic benefits as compared to the forecasted economic and political benefits of China and the challenges ahead.
\end{abstract}

Keywords: BRI, CPEC, Challenges, Development, Economic Benefits, Infrastructure, Transport.

\section{Introduction}

Following the "leap forward" economic initiative, the People's Republic of China has stood second strong economy in the world and wrapped up numerous enabling economic partnerships with different nations in Africa, Asia and Latin America (Ishida, 2009). The leap forward economic initiative has led China to the formulation of a strong economy which was supported by another initiative coined as "constructive engagement" with its equals. Through the motto of constructive engagement, China has won the confidence of different Governments starting from Southern Asia through Africa to Latin America. In this regard, China has shown a 
relaxed foreign exchange control, fewer investment restrictions to create a suitable condition for privately owned Chinese firms to participate in the international investment (Buckley et al., 2008).

China continues to appear as a major regional and global power and has embarked upon numerous economic and political initiatives worldwide (Chin and Liu, 2017, Chin et al., 2016). CPEC is the furtherance of China's desire to a shorter and costeffective route to Middle East Asia, Central Asia, Africa and the rest of the world. This will ultimately promote peoples' quality of life and will foster a pragmatic economic and trade cooperation. The idea of CPEC takes its origins from the transport corridor. Transport Corridors are the Channels or routes which link one economic center to another either within a nation or among multiple nations. When Transport Corridors are prolonged to a region, markets of the entire region can witness the advantage of enlarged multidimensional investment and trade. Continuing successful transport linkage in a region needs excellent infrastructure and large energy resources. Consequently, an Economic Corridor with a better concentration on improved infrastructure is developed as an Economic Corridor (Asian Development Bank, 2014). Furthermore, CPEC is only transportation corridor; China and Pakistan seek to augment economic connections through a plethora of developments and their impacts will be multiplied (see Fig 1, Internal map of CPEC with Projects Details; Markey, 2016, Boyce, 2017).

CPEC is a wide-ranging set of supportive projects and initiatives, which covers main areas including connectivity, industrial parks and industries, agricultural development, information network infrastructure, connectivity, energy cooperation, tourism, poverty alleviation, livelihood improvement including municipal infrastructure as well as financial cooperation, public health, education, and peopleto-people contacts by linking Kashgar with Gwadar through Gilgit-Baltistan and the other areas of Pakistan (Hussain, 2016). The CPEC has linkage of rail and roads measuring about 3000 kilometers, providing Pakistan its much-needed economic infrastructure, especially power-generation plants. Overall construction cost is expected about 46 billion US Dollar (Zhang and Shi, 2016) and the project expected to be completed by 2030. The completion of this project will not only open the Indian Ocean for China but it will also open the "new economic territory" for the whole world (Ibrar et al., 2016b, Ibrar et al., 2016a).

It is anticipated that Pakistan could appear as a center of trade and commerce in the region with the construction of the CPEC that would entail the establishment of numerous industrial and economic zones with railway and road linking Pakistan and China. (Sial, 2014). It is important for the policy makers of Pakistan to succeed the prearranged opportunity through proficient precision by converting the capacities of 
Pak-China corridor into sustainable and substantial economic development (Chaziza, 2016). CPEC will be fate and game-changer of Pakistan for its respective economies and regional connectivity and will increase mutual development. It is an optimistic and most welcomed project started to bring economic prosperity in Pakistan (Ibrar et al., 2017c, Ibrar et al., 2018d).

Even though the issue of the CPEC has been a subject of discussion and debate nationally and internationally, the most dominating points were circled on the selection of the route (Shah, 2015) and the impact of such economic overtaking on the relationship between Pakistan and India (Ibrar et al., 2018e). For more importantly Pakistan is counting on CPEC to drive future growth. In this regard, the discussions concerning the economic benefit of Pakistan and the ways how to ensure they were almost ignored. Hence, in this review of theory, this paper argues that Pakistan has to focus on the ways to ensure its benefits from the mutual projects and therefore we aims to address the following two important questions:

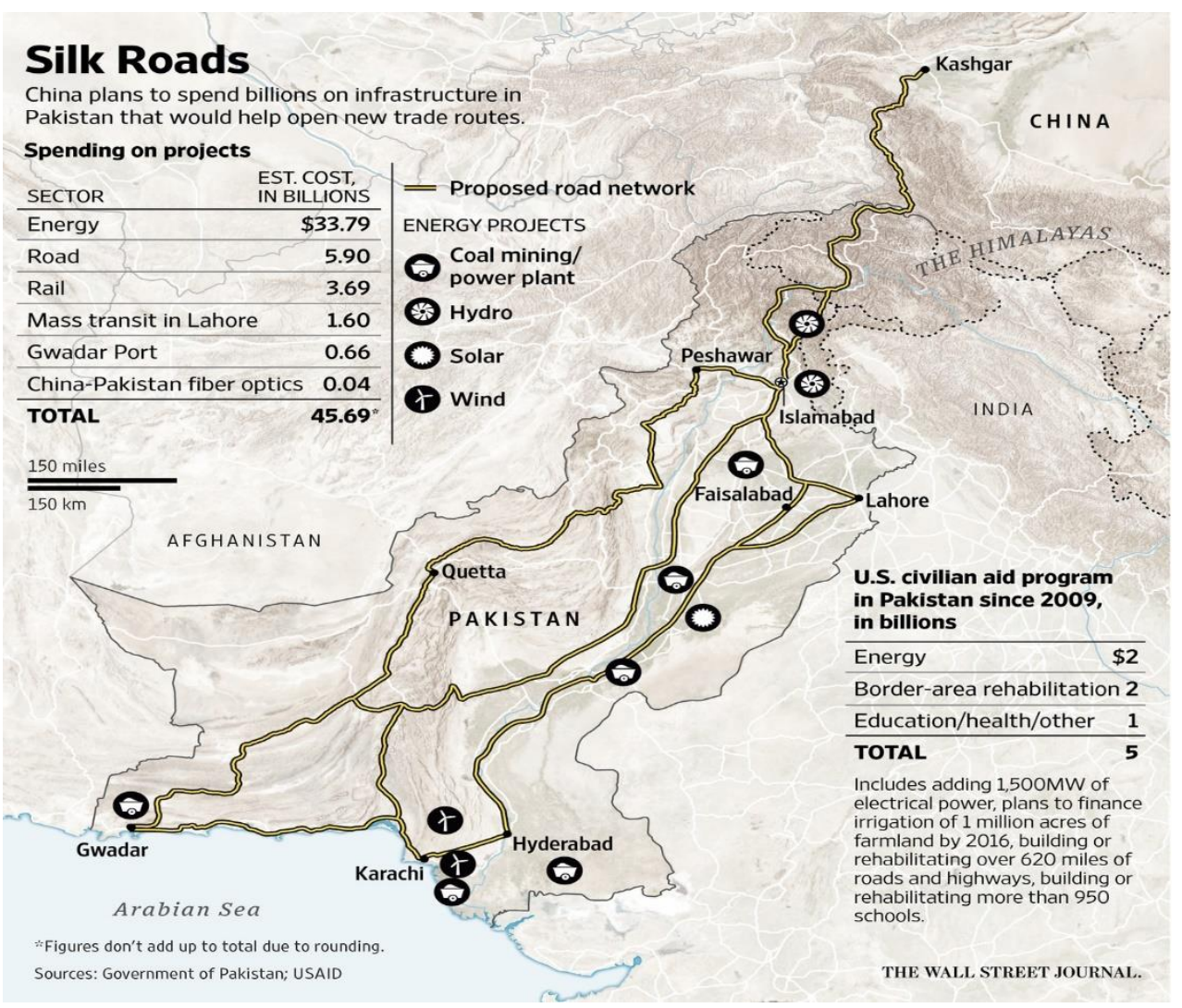

Figure. 1 Internal map of CPEC with Projects Details. Source:

https://www.siasat.pk/forum/showthread.php?412555-CPEC-Map-and-details 
- What are the expected challenges for the full implementation of the project?

- How can Pakistan ensure its fair share of economic benefits relative to the forecasted political and economic benefits of China?

\section{Strategic significance}

CPEC is situated at the junction of Silk Road Economic Belt and Maritime Silk Road. The core construction of CPEC is planned to be along the Karakoram Highway which was built the 1970s. Karakoram highway connects the border of China with Pakistan and thus it is considered to be the prime and ideal location for this project. This study is based on the evaluation of the economic development of CPEC on the local development of Pakistani society. The CPEC, a multi-billion US dollars development plan, is heralded as a 'game changer' for Pakistan's economic and regional development. Being an essential portion of a main development initiative organized by China, known as 'Belt and Road Initiative' (BRI), to link Asia with Europe, Middle East, and Africa, the CPEC is much linked to interests and hopes, , as well as global geopolitics and regional development (see Fig. 2). However, such major development never come without critical questions and challenges (Ibrar et al., 2016b, Ibrar et al., 2018f).

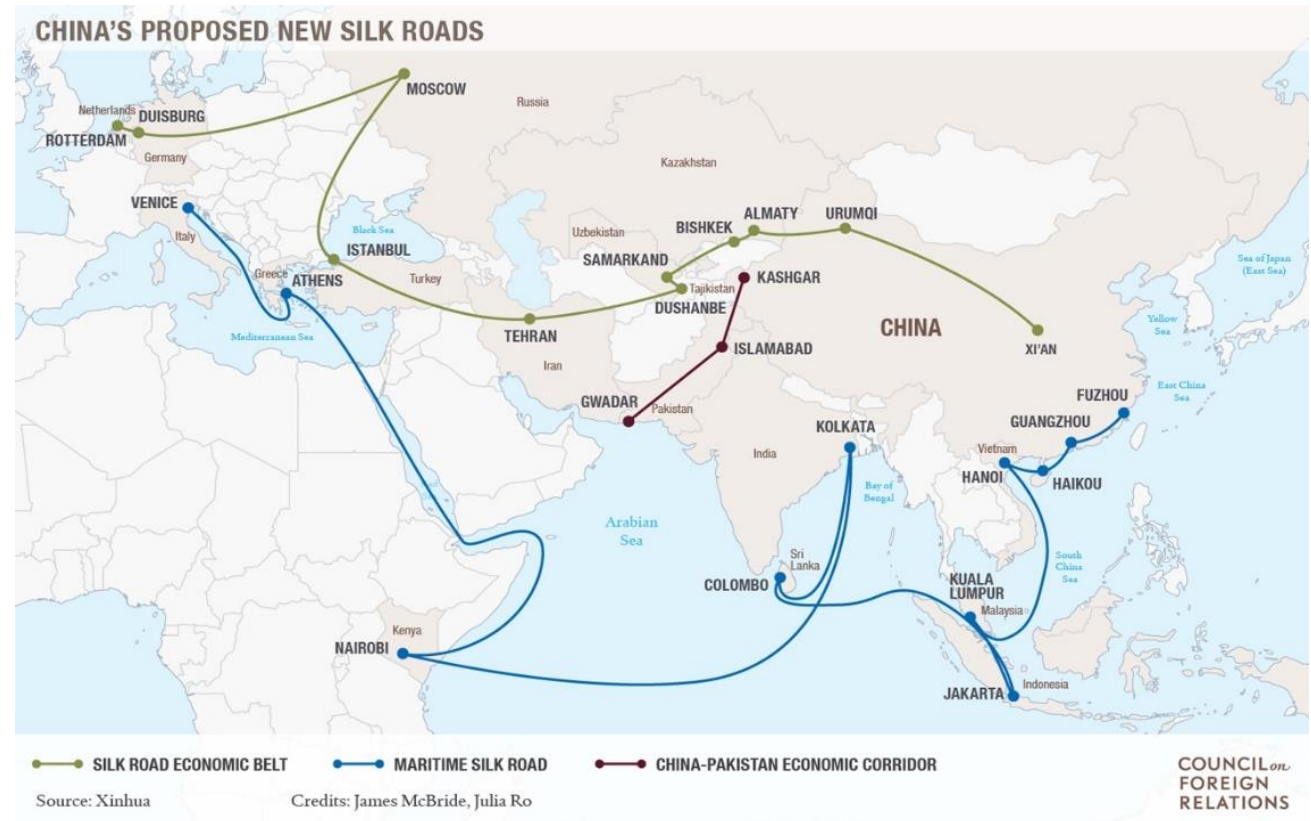

Figure. 2 CPEC in the framework of OBOR. Source:

http://herald.dawn.com/news/1153597/cpec-the-devil-is-not-in-the-details 
As a continuation of its "constructive engagement", China has widened its economic role in the South Asian region. The massive economic overtaking known as the CPEC is the reflection of such ongoing partnerships. It is the expansion of the free trade agreement signed in 2006 resulted in the trade volume expansion between China and Pakistan. According to Vandewalle (2015) the trade between China and Pakistan has expanded from 1 billion USD in 1998 to 15.15 USD billion in 2015 and laid a firm foundation for the creation and implementation of CPEC and it was formally launched in 2015 following after the official visit of Xi Jin Ping to Islamabad. CPEC is considered to have a potential impact on the overall macroeconomic improvement of Pakistan and China.

It is expected to create a huge employment opportunity for about 0.7 million people from both sides (Shaikh, 2016). On the other hand, the mega projects which include seaports, rail and road transportation, and energy sectors are expected to motivate the investment spirit of Pakistan which was drastically deteriorated by the terrorism prospects of the international community. Thus, for Pakistanis, the CPEC is an opportunity that cannot be ignored at any cost. With its networks of enabling infrastructures, it is the way out for the economic development of Pakistan in attracting further international investment and changing the image of the country with respect to the terrorism prospect (Ishida, 2009). According to Naseem (2015), due to the investment spirit it motivated, CPEC is expected to increase the gross domestic product (GDP) of Pakistan by $1.5 \%$ in the next three years. Furthermore, Pakistan Observer (2017) reports recent facts about Pakistan's gross domestic product (GDP) that industrial sector already recorded a remarkable growth of $6.8 \%$ which is a record in the last eight years. The CPEC has brought an unprecedented boost in Pakistan exports in the current fiscal year around 17 billion US dollars. However, for many, the project has more economic benefits for China, and many experts considered it as the reflection of China's power expansion in the world (Ramay, 2015, Yiwei, 2015, Shaoshi, 2015).

CPEC appears as a vital mission in China and Pakistan. For China, it affords a substitute safe way to import oil and gas and provides new markets. For Pakistan, it helps counters Indian influence in the region. Additionally, a number of experts believe that the CPEC will have more benefit to Beijing and Chinese investors as compared to its benefit to Pakistan. In the same vein, provides more clarification how China will get more benefits from Pakistan because China is lending Pakistan for construction, but the labors will be executed from their own companies workforce by debt to equity ratio of around 80:20. 


\section{CPEC from Pakistan's Perspective:}

A number of analysts have tried to understand the manner of benefits of the mega projects to the collaborative countries other than China. In reaction to such expert intentions, China has provided its own analysis and expressed its resolutions. In the white paper released in August 2011, China has expressed that the collaborations are aimed at strengthening the self-development and capacity of recipient countries, and as an impact, it will improve the livelihood and prosperity of the people of both countries (Kitano and Harada, 2016). In this regard, CPEC will generate more than two million employment opportunities to Pakistani locals.

In spite of differences in political and cultural setup between both nations, Pakistan had a long-lasting political and economic and relationship with China since 1947 to till now. The current CPEC is, therefore, a well-planned partnership initiated by the free trade agreement between the two countries that resulted in a huge expansion of the trade volume between both countries. It is anticipated that with the development of CPEC will have four interconnected strategic significances for Pakistan.

First, it will stimulate the deteriorated investment essence of Pakistan and guarantee the inflow of billions of US dollars of investment from Chinese conglomerates. The infrastructure of rail, road transport and communication, ports, and facilities along with the availability of sustainable energy sources will motivate the investment spirit which us affected by the terrifying. In addition, it will attract further FDI from China and other nations. Second, it will help China to intensify the shipping of its products to Africa, Middle East, and Europe. Moreover, the gas and oil channels will ensure the sustainable supply of energy for the demanding Chinese economy. Third, with its 3000-kilometer coverage, the CPEC will guarantee the connectivity of the Southern and Eastern parts of the Asian regions and will help the economic development of backward areas in both Pakistan and China. Fourth, in addition to strengthening economic ties between both nations, the CPEC is anticipated to create a shift in the political and economic position of China in the world (Bhattacharjee, 2015, Perveen and Khalil, 2015, Ranjan, 2015). On the other hand, the ChinaPakistan relationship held at the diplomatic level will transform into strong economic bonds on the micro and macro level for better mutual understandings.

\section{CPEC from Chinese Perspective:}

"All-weather strategic partnership" was lifted after the visit of Chinese President Xi Jinping in Pakistan. This "All-weather strategic partnership" produced a cloudy environment of mega investment in different projects between two countries were 
gearing up for an expansion in various fields; China is struggling to achieve multitude interests high on agenda. The success of CPEC will also provide China with direct access to the Indian Ocean which along with the economic benefits will boost the political influence of China in the southern and central parts of Asia (Bhattacharjee, 2015).

Furthermore, through this, China will ultimately get access in Russia and "Greater Europe". So, given the importance to this, OBOR has become the far-reaching element for the Chinese economy and political diplomacy. This economic, political and diplomatic domination will change Asia's outlook in the world, through global power equation and Central Asia will have the ability to play an independent role irrespective of global energy and geopolitical scenario. More broadly, China hopes with the revitalization of the regional economy of the Uighur population in Xinjiang province, where actually this economic corridor initiated (Strasser, 2016) that was not so developed.

\section{Challenges ahead}

Similar to other large-scale economic breakthroughs, CPEC is full of challenges. Many of the domestic and international discussions and debates concerning the mega projects indicate that a fair share of the possible challenges comes from four big sources. First and foremost, experts in the area have a consensus on the important impediment to the regional and national peace and stability on the planned projects. The peace and stability of the region and Pakistan itself are the guarantees for the free movement of Chinese experts and workers that may either hinder or motivate the completion of the projects within the specified time period. The second challenge is related to the lack of professional expertise for Islamabad to complete the enabling transport and communication infrastructures that can facilitate the start and completion of the mega-projects in time (Ishida, 2009). The lack of such expertise might be one of the reasons for Beijing to look for alternative routes in different countries. Third, due to its geopolitical conditions, the economic objectives of the projects might be challenged by both internal and external forces. Such forces might sponsor internal violence and terrorism to sabotage the projects. Fourth, the administrative functions related to bureaucracy, corruption, and nepotism are also the biggest internal challenges of Pakistan that can affect the project. Fifth, the largest highway networks, however, face difficulties regarding work conditions, terrain, and opposition and is viewed by many as more long-term connectivity projects (Ahmad et al., 2017). 
Currently, this project is receiving huge criticism and is hotly debated with respect to the geographical location of the route. Incidents such as the Balochi insurgency happened in 2004 as an opposition to the Gwadar port will have a negative impact on the completion and implementation of the project and on possible strategic changes of Beijing. If these issues are minimized then the main focus should be on; how both countries' administrations might hinder the implementation and completion of the project, because they might be one of the main factors for the crack in this project (Masood, 2016). Long-term administrative stability in Pakistan is crucial for smooth developments like the CPEC. In the past, Pakistan has gone through stages of administrative instability and uncertainty that deteriorated the nation's roadmap development and also affected policy regularity. For the smooth development of CPEC, both Pakistan and China need to make plans on time to handle these challenges.

\section{Ensuring Pakistan's economic benefits}

The achievement of pre-stated economic and political objectives of an economic corridor entirely depends on the level and continuity of government commitment and the economic and geopolitical characteristics of the collaborating regions (Ishida, 2009, Brunner, 2013). When it comes to the economic role of CPEC, the establishment of communication and transportation infrastructures in Pakistan will trigger the investment spirit in the country which is expected to enable thousands of new ventures to flourish domestically. In addition to that, the availability of enabling institutional infrastructure and institutions will attract foreign direct investments from different parts of the world (Brunner, 2013, Mehar, 2017)). However, with the prospects of the aforementioned challenges, the economic benefits of the country might be challenged. On the other hand, in case the win-win paradigm of the opposed economic partnership with China doesn't work, still, the achieved economic benefits of Pakistan might be less than the intended and China might be the beneficiary. Wise policy decisions would enable Pakistan to overcome the challenges and exploit the opportunities (Nasreen, 2016). To counteract with such problems, the central government of Pakistan will need to focus on the following points.

\section{Continuous Government Commitment:}

The continuity of the commitment of the central government is the foundation for every aspect of Pakistan's economic benefit to following from the mega project. For instance (Ishida, 2009) concluded that the commitment of the central government is part of the peace and stability package of the country that will have an effect on the level of economic benefit. As a decision-making body of the country, the creation of 
economic and capacity development that can absorb the huge investment to come. On the other hand, the commitment of the central government to carry the preplanned projects will enable to have an effective negotiation with the respective stakeholders to agree on the reliable routes and will influence the level of economic benefits of Pakistan.

Thus, promises for the construction of the remaining two supplementary routes should be kept by the central government (Ishida, 2009, Bhattacharjee, 2015) and keep negotiating with the opposition parties. Moreover, the commitment of the central government will ensure the benefit of the country not only at the implementation stage of the project but also at every stage of the construction of the infrastructures (Ishida, 2009). Pakistan's Prime Minister has given clear instructions regarding CPEC to his incumbent Government; all the projects underway in Gawadar through CPEC will be completed in his tenure and specifically project "energy harvest", to be completed by 2018 (Rehman, 2017).

\section{Agreement and Consensus about the Route's Location:}

The internal disagreement among the stakeholders in Pakistan concerning the geographical location of the route will create a safety concern for the Chinese experts and workers (Ishida, 2009). Many experts believe that the unnecessary political squabbling between the ruling and the opposition parties will have an adverse effect on the projects and impact future investments (Ishida, 2009). Moreover, the issue of disagreement of the parties will create instability in the country and will question the safety of the Chinese experts which in turn might push Beijing to look for an alternative route (Ishida, 2009, Brunner, 2013). Thus, a commitment of all parties to reach an agreement and consensus could be an important input for the success of the projects.

\section{Capacity Development:}

For many, a large part of the challenge and impediment for the successful completion and implementation of the CPEC springs from the low absorption capability of Pakistan's economy and labor skills (Ishida, 2009). As a developing country, both the economic and educational systems of the nation might not be able to support the huge investment related to the construction of transportation, communication, and power infrastructures. Therefore, in order to be on the safe side and benefit from the economic breakthroughs, Pakistan needs to have a capacity development program starting from the vocational schools where technical skills are developed to the highest level of its educational sectors (Brunner, 2013, Mehar, 2017). Specifically, in this regard, Chinese Ambassador Sun Weidong announced a project with the stage of "grand development" and offering 220 Chinese Government Scholarships to 
South Pakistani students that will help to produce talented students for the implementation of the project under CPEC. After completing their education from China, these students can gain benefit because of the understanding of Chinese culture and technological standards, as a great competitive advantage when they find an opportunity in the future.

\section{Intention to Benefit throughout the Process:}

Economic partnerships that include China were subjected to critics concerning its ability to empowering partnering countries to have the necessary technological and economic transfer. Chinese international investments were time and again reported for extensive pollution, poor community relationship, 100\% Chinese labor force utilization. China's economic aid and collaboration packages are tuned with the idea of boosting the export volume of its materials, thus, the overall economic effect of Chinese aid money on the recipient countries was found to be almost zero (Bhattacharjee, 2015). According to Bhattacharjee (2015), existing economic collaborations with China, especially with Africa, have shown that necessary project materials and labor forces of the agreed financial packages are brought from China mainland and even salaries of employees are paid directly to the families in the mainland, not to the Chinese workers in the recipient country. Therefore, the overall effect of Chinese collaboration economic projects is bringing only limited economic and technological progress for collaborating governments.

In addition to that, most of the recipient nations are afraid of the strong appetite of China for natural resources and the low economic and technological transfer to the local community. For instance, with its partnership with Africa and Latin America, Beijing was criticized on the usage of the Chinese labor force at every level and limited the financial and technological transfer to the local people. Thus, the central government of Pakistan should make sure that the people of Pakistan will have a fair share of benefit out of the project at each level. For this purpose, the government should be strong enough to force the Chinese investors the legal structures and regulations of the country. Instead of allowing China to circulate the project money by paying it to Chinese labor, part of the project money needs to be circulated within Pakistan so as to uplift the poor to the position it supports the implementation of the project. In addition to that, the Pakistani Government should empower its citizens and create necessary skills so as for the country to have reliable technology transfer (Mehar, 2017). 


\section{Conclusion}

CPEC is initiated on the bases of previous free trade agreements is such an extraordinary economic partnership between Pakistan and China. Regardless of their difference in the political setup, the two nations had various forms of economic ties since the 1950s. However, no previous economic package between the two nations is comparable in size and overall objective to the ongoing CPEC mega-project. The project which includes ports, energy, transportation, and communication infrastructures has been the center of domestic and international debates and discussions with due concern given to its geographical location in Pakistan and its influence on the Pakistan-India power balance. An enormous concentration on both the geopolitical situation, however, has made Pakistan forget the concern about how to ensure the economic benefit out of the mega-project. This paper, therefore, has investigated and analyzed the possible challenges and impediments of the construction and implementation of the projects and we forwarded relevant recommendations to the Pakistani central government on how to ensure better economic advantage out of it.

Alongside the efforts to mitigate the political and ideological challenges, the Pakistani central government should have a thorough understanding of the projects and need to devise strategies to have a possible economic benefit at each level. Lessons should be learned from the Chinese economic partnership with Africa which becomes the focus of Chinese private and public investment due to its ample natural resources. An enormous amount of monetary packages were agreed to support the development agendas of different countries on the continent. However, in the implementation of the projects, local material and labor markets were overlooked and the projects have served only the Chinese labor force as well as the Chinese logistics service. The main reason for China to use mainland workforce was a lack of skilled manpower in the local market of African countries (even for the daily construction laborers). In effect, not a single dollar from agreed Chinese investment package was utilized by locals in the overall process. Therefore, to avoid such problems, the central government of Pakistan needs to show adequate commitment to creating human resource competence. The level of government commitment will enable successful negotiation and will also create the possibility of better benefit from the implementation of the projects.

\section{Acknowledgment}

This research was financially supported by the National Natural Science Foundation of China 
(Grant NO. 71673068). The authors would like to thanks, all subjects who helped with this research.

\section{References}

Ahmad, M. S., Asmi, F., Ali, M., Rahman, M. M. and Abbas, S. M. (2017), "China-Pakistan Economic Corridor: In the context of 'String of Pearl Strategy", International Journal of Business and Social Research, Vol. 7 No. 8, pp. 26-42.

Asian Development Bank. (2014). "Developing economic corridors in South Asia", available at: https://www.adb.org/publications. (Accessed 27 April 2017).

Bhattacharjee, D. (2015). "China-Pakistan economic corridor (CPEC)", Indian council of world affairs, Issue brief No. 13, India.", available at: www.icwa.in/pdfs/IB/2014/CPECIB12052015.pdf (Accessed 13 August 2016).

Boyce, T. (2017). "China-Pakistan Economic Corridor: Trade Security and Regional Implications", available at: http://www.osti.gov/scitech (Accessed 20 April 2017).

Brunjes, E., Levine, N., Palmer, M. and Smith, A. (2013). "China's Increased Trade and Investment in South Asia (Spoiler Alert: It's The Economy)", available at: www.lafollette.wisc.edu/publications/workshops.html (Accessed Asad Rafi, Farid Khan and Sabah Aslam15 April 2014).

Brunner, H.-P. (2013). "What is Economic Corridor Development and what can it Achieve in Asia's Subregions? DB working paper series on regional economic integration, Asian Development Bank, Philippines.", available at: www.adb.org/publications/economiccorridor-development-and-what-it-can-achievein-asia-subregion. (Accessed 24 August 2016).

Buckley, P. J., Cross, A. R., Tan, H., Xin, L. and Voss, H. (2008), "Historic and emergent trends in Chinese outward direct investment", Management International Review, Vol. 48 No. 6, pp. 715-748.

Chaziza, M. (2016), "China-Pakistan Relationship: A Game-changer for the Middle East?", Contemporary Review of the Middle East, Vol. 3 No. 2, pp. 147-161.

Chin, T. and Liu, R.-h. (2017), "Critical management issues in China's socio-economic transformation: Multiple scientific perspectives to strategy and innovation", Chinese Management Studies, Vol. 11 No. 1, pp. 12-18.

Chin, T., Tsai, S.-B., Zhu, W., Yang, D., Liu, R.-h. and Tsuei, R. T. C. (2016), "EOperformance relationships in reverse internationalization by Chinese global startup OEMs: social networks and strategic flexibility", PloS one, Vol. 11 No. 9, p. DOI: 10.1371/journal.pone.0162175.

Hussain, E. (2016), "China-Pakistan Economic Corridor: Will It Sustain Itself?", Fudan Journal of the Humanities and Social Sciences, pp. 1-15.

Ibrar, M., Jianing Mi and Rafiq., M. (2016a), "China Pakistan Economic Corridor: SocioCultural Cooperation and Its Impact on Pakistan", in 5th EEM International Conference on Education Science and Social Science (EEM-ESSS 2016), Sydney, Australia, pp. 179-83.

Ibrar, M., Mi, J., Rafiq, M. and Karn, A. L. (2016b), "The China-Pakistan Economic Corridor: Security Challenges", in The 2016 2nd Asia-Pacific Management and Engineering Conference (APME 2016), Shanghai, China, pp. 71-76. 
Ibrar, M., Mi, J., Karim, S., Laghari, A. A., Shaikh, S. M., \& Kumar, V. (2018c). Improvement of Large-Vehicle Detection and Monitoring on CPEC Route. 3D Research, 9(3), 45.

Ibrar, M., Mi, J., Mumtaz, M., Rafiq, M., \& Buriro, N. H. (2018d). The Importance of ChinaPakistan Economic Corridor from Regional Development Perspective. Paper presented at the 31st International Business Information Management Association (IBIMA 2018), Milan, Italy.

Ibrar, M., Mi, J., Mussawar, S., \& Rafiq, M. (2017e). "Community Awareness about Family Planning Program in District Malakand, Pakistan. Paper presented at the The 30th International Business Information Management Association (IBIMA 2017), Madrid, Spain.

Ibrar, M., Karim, S., Shah, M., Durrani, D., \& Ali, L. (2018f). "Theoritical Perspectives on China-Pakistan Economic Corridor. Paper presented at the The $32^{\text {nd }}$ International Business Information Management Association (IBIMA 2018), Seville, Spain.

Ishida, M. (2009). "Special economic zone and economic corridors", ERIA discussion paper series, Institute of Development Economics, Development Dtudies Center, Japan", available at: http://core.ac.uk/download/pdf/9306181.pdf (Accessed 10 August 2016).

Kitano, N. and Harada, Y. (2016), "Estimating China's Foreign Aid 2001-2013", Journal of International Development, Vol. 28 No. 7, pp. 1050-1074.

Markey, D. S. (2016). "Behind China's Gambit in Pakistan (As an expert briefing in "council on foreign relations")", available at: http://www.cfr.org/pakistan/behind-chinas-gambitpakistan/p37855 (Accessed 24 April 2017).

Mehar, A. (2017), "Infrastructure development, CPEC and FDI in Pakistan: is there any connection?", Transnational Corporations Review, pp. 1-10.

Masood, T. (2016). "CPEC challenge and opportunity", available at: https://tribune.com.pk/story/1250681/cpec-challenge-opportunity/ (Accessed 01 December 2016).

Naseem, A. (2015). "Impact of China Pak Economic Corridor - A Bird's Eye View", [online] Islamabad: BMA Capital", available at: http://investorguide360.com/wpcontent/uploads/2015/05/Impact-of-China-PakEconomic-Corridor-A-Birds-Eye-View.pdf. (Accessed 28 June 2016).

Nasreen, F. (2016). The new Great Game in Central Asia : Challenges and Opportunities for Pakistan Central Asia in the 21 st Century, I(1), 18-25.

Pakistan Observer. (2017). "Macro and Micro Dividends of CPEC", available at: http://www.cpecinfo.com/cpec-news-detail?id=MjAyMA== (Accessed 27 April 2017).

Perveen, S. and Khalil, J. (2015), "Gwadar-Kashgar Economic Corridor: Challenges and Imperatives for Pakistan and China", Journal of Political Studies, Vol. 22 No. 2, p. 351.

Ramay, S. A. (2015). "China Pakistan Economic Corridor: A Chinese Dream Being Materialized through Pakistan", Policy Brief, Sustainable Development Institute, Pakistan", available at: https://sdpi.org/publications/files/China-Pakistan-EconomicCorridor-(Shakeel-Ahmad-Ramay).pdf. (Accessed 12 August 2016).

Ranjan, A. (2015), "The China-Pakistan Economic Corridor: India's Options", Institute of Chinese Studies, Vol. 10, pp. 1-25.

Rehman, S. u. (2017). ""Gawadar is the business hub for the whole region and the incumbent government wants to complete all CPEC projects on priority basis": Analysts", available at: http://www.radio.gov.pk/15-Mar-2017/gawadar-is-the-business-hub-for-the-wholeregion-and-the-incumbent-government-wants-to-complete-all-cpec-projects-onpriority-basis-analysts (Accessed 23 April 2017). 
Shah, S. (2015). "China's Xi Jinping Launches Investment Deal in Pakistan", available at: https://www.wsj.com/articles/chinas-xi-jinping-set-to-launch-investment-deal-inpakistan-1429533767 (Accessed 23 August 2016).

Shaikh, N. A. (2016). "CPEC To Create Over 700,000 Direct Jobs", available at: http://pakchinanews.pk/cpec-to-create-over-700000-direct-jobs/ $\quad$ (Accessed 31 December 2016).

Shaoshi, X. (2015). "Vision and Actions on Jointly Building Silk Road Economic Belt and 21st-Century Maritime Silk Road", National Development and Reform Commission, Ministry of Foreign Affairs, and Ministry of Commerce of the People's Republic of China, with State Council authorization. ", available at: http://en.ndrc.gov.cn/newsrelease/201503/t20150330_669367.html. (Accessed 13 July 2016).

Sial, S. (2014), "The China-Pakistan Economic Corridor: an assessment of potential threats and constraints", Conflict and Peace Studies, Vol. 6 No. 2, p. 24.

Strasser, F. (2016). "China-Pakistan Economic Corridor: A Road to Peace? (Analysis and Commentary)", available at: https://www.usip.org/publications/2016/12/china-pakistaneconomic-corridor-road-peace (Accessed 18 April 2016).

Vandewalle, L. (2015). "IN-DEPTH ANALYSIS Pakistan and China: 'Iron brothers' forever? (Policy Department, Directorate-General for External Policies)", available at: www.europarl.europa.eu/RegData/etudes/IDAN/.../EXPO_IDA(2015)549052_EN.pdf (Accessed 14 June 2016).

Yiwei, W. (2015), "China's "New Silk Road": A Case Study in EU-China Relations*", in Amighini, A. and Berkofsky, A. (Eds.) ISPI Report Xi's Policy Gambles: The Bumpy Road Ahead, ISPI, Beijing, China, pp. 92-109.

Zhang, R. and Shi, G. (2016), "Social impacts assessment for China-Pakistan Economic Corridor investment activities", Energy, Vol. 33, p. 76-82. 